\title{
Seventeenth-Century Jurisprudence and Eighteenth-Century Lexicography: Sources for Johnson's Notion of Authority
}

\author{
John Stone \\ UNIVERSITY OF BARCELONA
}

\section{INTRODUCTION}

This paper attempts an investigation of two sustained similes (language is like law/language is like liberty) in Samuel Johnson's lexicographical tracts. Law, language, and liberty are here treated as key concepts in the continuing appeal that eighteenth-century Englishmen made to a mythologised English past, an appeal at whose rhetorical centre lies constitutional law in history - what J. G. A. Pocock calls the "myth of the confirmations" of 1066, 1215, 1628, and 1688 (232). I argue that the intellectual origins of Johnsonian standard English lie in Sir Edward Coke's early seventeenth-century restatement of common law doctrine and terms. Salient issues are common law's need to give an account of its antiquated, medieval vocabulary and its place in the constitutional conflict of the seventeenth century.

The chief loci of such similes are Johnson's Plan of a Dictionary and Dictionary; they have to do with the sort of standard English there discussed. Before asking what Johnson thought of the idea of a standard, one must, proceeding in one direction, ask what he thought of English, and what he thought about language. Proceeding in another direction, the necessary questions have to do with the ways in which things are governed or regulated.

Even so provisional an essay in the history of debates over fixing a standard for English would be incomplete without a Continental background. The Accademia della Crusca was founded in 1552 , its chief aim being the purification of the language. It is notable that its heraldic device was a sieve. All five founders were noblemen, members of the Florentine Academy. A dictionary composed on Tuscan principles was published in 1612, at Venice. This work, in addition to espousing one region's literary dialect over the others', promoted the notion that the fourteenth century had been the golden age of the Italian language. Its attempt to fix a standard for a modern European language was admired and emulated.

With the establishment of the Académie française in 1635 the history of institutions, and of discipline as derived from the apparatus of the state, extends in a new way to writing. Cardinal Richelieu, while never a member of the Academy, was the mover behind plans to grant royal letters patent to a group of literary men who had met since 1629 to discuss literary topics. When pre-revolutionary academies were done away with in 1793, the Académie française perished with them, but it was reconstituted two years later as part of the Institut de France.

The purpose for which the Academy was founded, as set forth in its statutes, was the purification of the French tongue. A civic office had taken the place of a religious one, and the new Nihil Obstat that the Académie was empowered by the Crown to dispense referred to purity not of doctrine but of style. To this end the Academy members were pledged to produce a dictionary, a grammar, a treatise on rhetoric, and one on poetry. The dictionary, when it appeared in 1694, secured the state's approbation of some words and recognition for some meanings. Other words, other meanings were proscribed. 
The French Academy had authorities for its dictionary: writers from a golden age whose usage was to be revered. These authorities are the hidden text of the Academy's dictionary as published in 1694; citations were the basis for philological labour but were not themselves included.

A catalogue of the most approved authors could not provide examples of many words from trade, manufacture and science, and so they were left out. The Italian example is more curious: since the time of its foundation, it had been the task of the Accademia della Crusca to supervise the development of the vernacular as a literary medium. Having determined that words for the Vocabulario were to be drawn from a canon of literary works and having found that no such works could be found to furnish important terms of skilled work and commerce, the Accademia commissioned one of its members, the poet and playwright Michelangelo Buonarroti the Younger, to add to the canon. He wrote the comedy La Fiera (1618) to supply the want. Johnson cites Buonarroti's efforts and remarks that the exclusive criterion that had made La Fiera necessary had been subsequently somewhat relaxed (453).

Inevitably, these notions of a fixed, standard written language had their influences on England. Impulses towards standard English come, explicitly, from three camps. Defoe, Swift, and other writers were keen on an academy because they saw civic prose as part of the job of the professional writer. They wanted a medium that would be understood as easily as possible by readers of different backgrounds, regions, and ages. In their and other proposals for an instituted authority the examples of the French and Italian language reform are always present. English writers portray English as corrupted (since the Civil War, or the Restoration, depending on the writer's political sympathies) and little refined.

Baconians and scientists (John Wilkins, John Glanvill) already had one model of "normalised" prose - the close, naked, natural style that Thomas Sprat describes, advocates, and hopes to exemplify, and that Glanvill, in his revisions of his own work, does everything to illustrate. The emphasis was on the invariable, on meanings that could be trusted to stay put with the passing of years, and on a style that was (so they thought) no style at all inasmuch as it eschewed the faddish and the fashionable. The invented ideograms of Wilkins's "real character" are an attempt to carry those principles further than English itself would allow.

In England there are two well-discussed movements towards standard English, and in France a powerful, prestigious model. Yet Johnson, by the time he composes the "Preface", has opted for a reasonable, arguable standard English based on precedents whose interpretation may be disputed and whose value may vary with the years. Indeed, Johnson states that common usage is, for the greater part of the English vocabulary, an authority equal to that of the authors cited, the precedent that stands before the precedents. Moreover, Johnson tells us he has had to sift through seemingly contradictory precedents to discover, by induction, the "decrees of custom"; he draws an analogy between the English constitution (part of the common law, rather than the other way around) and the English language. He connects both to English liberty.

The terms of his argument, the techniques of his lexicography, the resignation that he makes to a "degeneration" that can be retarded but never repelled, his resistance to a Continental model, his balancing of quotable authorities and common usage: all seem echoes of the common law. In Johnson's own similes for a normalised language there contend two notions of how the law might function: a codified, purified law built from and interpreted according to reason; and a law amassed from the particulars of experience, developed by a complex mixture of analogy and custom. He chooses the latter.

How Johnsonian standard English is to be governed might best be extracted from the Plan of an English Dictionary in the form of an image: two magnets govern the space of linguistic decision-making, not by attraction but repulsion. Let us imagine two fixed magnets the negative poles of which point to one to another. One pole is the authority of custom:

So we usually ascribe good but impute evil; yet neither of these words, nor, perhaps, of any in our licentious language is so established as not to be often reversed by the correctest writers. I shall therefore, since the rules of style, like those of law, arise from precedents often repeated, collect the testimonies on both sides, and 
endeavour to discover and promulgate the decrees of custom, who have so long possessed, whether by right or by usurpation, the sovereignty of words. (444)

That this role corresponds to that of a common-law judge working on a point of case law is clear from the terms Johnson chooses to describe his expected actions. This pole asserts that custom governs words, and its push would seem to vary on the part of the lexicographer's task undertaken at any given moment. As this passage appears in the section on defining, one might assume that definition is governed more by custom, less by the other pole.

Censure stands opposed to custom:

Barbarous or impure words and expressions may be branded with some note of infamy, as they are carefully to be eradicated wherever they are found... If this part of the work can be well performed it will be equivalent to the proposal made by Boileau to the academicians, that they should review all their polite writers, and correct such impurities as might be found in them, that their authority might not contribute, at any distant time, to the depravation of the language. (445)

Again, the judge of purity is Johnson as appointed to the bench by Chesterfield, who is very high up in the government of the state. The conferring of authority by such a procedure is not equivalent to the royal letters patent procured for the French Academy by Richelieu, but Johnson never comes closer to an invocation of the French model.

Between these poles words fall like metal shavings, and one must ask whether the words governed are so governed forever, or merely for now; whether the Dictionary is to fix a standard English, or describe a standard English already existing.

In the Plan two models overlap: the first, which is confidently prescriptivist, is that of a correct standard of meaning and usage from which deviations are to be proscribed; the second mixes desire for a standard with a description of those features of English that preclude a fixed or frozen standard. The latter model is one of resigned prescriptivism. Johnson at the beginning and the end of the Plan makes Continental claims about fixing and ascertaining the language, which in the middle of the Plan he sometimes flirts with, sometimes rejects. Johnson the confident prescriptivist has his moments of rhetorical triumph, where he compares his task to that of the Romans bringing law to the ancient Britons (445), and in the section on pronunciation (441). Pronunciation he wants fixed and thinks fixable - "since one great end of this undertaking is to fix the English language, great care will be taken to determine the accentuation" (441). Johnson's treatment of every other field - orthography, grammar, syntax, definitions, register, and choice of authorities - contains some disclaimer, some moment in which Johnson either questions his own authority or leaves doubts as to the extent to which a language may be fixed. Everywhere he endeavours, but he does not always promise to succeed. In orthography he is nearly as confident as in pronunciation; in syntax and grammar, he thinks a standard that adheres to reason and aspires to permanence too much to ask. To describe participles and plural inflections is, by Johnson's admission, to describe something that will not last:

And who upon this survey can forbear to wish, that these fundamental atoms of our speech might obtain the firmness and immutability of the primogenial and constituent particles of matter, that they might retain their substance ... But this is a privilege which words are scarcely to expect; for, like their author, when they are not gaining strength, they are generally losing it. Though art may sometimes prolong their duration, it will rarely give them perpetuity. (442)

Similarly, the "syntax of this language is too inconsistent to be reduced to rules" (443). Syntax and grammar, then, are two instances of Johnson's resigned prescriptivism: some aspects of language cannot be fixed or ascertained, and Johnson will provide only terms of debate (issues at hand and a line of precedents in the case of syntax) or descriptions of what has been "thrown together by negligence, by affection, by learning, or by ignorance" (442). We have the concession that some rules are derived chiefly from common usage, that common usage changes, that languages are formed and deformed in amidst the spittle and wind of the human mouth. Custom, conceived of as a thing in evolution, is at least as powerful as analogy or reason; where custom is 
inconsistent, one looks to precedents and searches, inductively, for the hint of a rule. At times "it is not in our power to have recourse to any established law of speech," and "we must remark how the writers of former ages have used the same word, and consider whether [the suspect writer] can be acquitted of impropriety, upon the testimony of [another writer]" (443) - id est, that some questions must be referred to a wider court.

The two models discussed above appear again in the "Preface" to Johnson's Dictionary as published in 1755, where they overlap in a less confusing manner. Sledd and Kolb date the "Preface" between April 1753 and the summer of 1754 (110), after Johnson and his Scottish amanuenses had been at work for six or seven years. The "Preface" is nearly half as long again as the Plan; it is neither addressed to Chesterfield nor signed. It was published at the beginning of the Dictionary when the latter finally appeared in the spring of 1755. Its unmarked structure is as follows: introduction; orthography; pronunciation; etymology; word choice and classification; grammar (one paragraph in the "Preface", whereas the Dictionary contained a "Grammar"); defining; authorities; syntax; and assessment of the labour the Dictionary had represented, its achievements and limitations.

Other prefaces and advertisements were appended to later editions, but the "Preface" was not replaced, nor revised. In the "Preface to the Octavo Edition of the English Dictionary", 1 Johnson made the only statement that might be construed as a claim that his work was a standard:

Having been long employed in the study and cultivation of the English language, I lately published a Dictionary like those compiled by the academies of Italy and France, for the use of such as aspire to exactness of criticism, or elegance of style. (455)

Full-blooded Continental prescriptivism is here tempered by the qualifying phrase describing dictionary-users whose desire it is to attain proficiency in the twin skills of reading and writing. It is for their sake that prescriptivism is not abandoned but adapted; there remain "improprieties and absurdities, which it is the duty of the lexicographer to correct or proscribe" (446).

The whole first section is a mixed apology, polemical tract on orthography and general exposition of Johnson's linguistic ideas. The "Preface" begins by making clear that experience and analogy are the first tools in English dictionary-making, "general grammar" being of little use. Analogy impels him to spell according to etymology; experience compels him to make exceptions. Analogy and ancestor worship require a return to some earlier spellings, but experience insists that "words are the daughters of the earth, and that things are the sons of heaven" (447). Words have changed because they are produced by human work, which is the imperfect forming of an imperfect thing. Once an imperfection has settled into place and entered into general use, it is best not to disturb it, however incongruent with rules of phonetics, or with the word's own history. Johnson repeats that "for the law to be known, is of more importance than to be right" (447).

Some sentiments expressed in the Plan are repeated in the "Preface". Again, in Johnson's treatment of orthography, there appears a defence of established practice (Johnson asks that innovators respect "the orthography of their fathers" [447]), a warning against change and an advocacy of constancy. "I have attempted few alterations," Johnson admits, "and among those few, perhaps the greater part is from the modern to the ancient practice." He is obliged to pick and choose among precedents, some fresher than others. Here are no reforms: no spelling unsupported by citations can displace a spelling commonly found. Where common usage varies, Johnson takes sides. Where it does not, "I have been often obliged to sacrifice uniformity to custom; thus I write, in compliance with a numberless majority, convey and inveigh" (447).

\footnotetext{
1. The octavo edition was an abridgement that retained the names of the authorities quoted in the folio edition: the quotations themselves were omitted. It appeared in an edition of 5,000 copies in 1756, the first of eight editions in Johnson's lifetime. While scholarly interest has traditionally focused on the folio Dictionary (of which Johnson only substantially revised the fourth edition, published in 1773), the best-selling octavo edition is by far the more important monument in the history of the book trade.
} 
Emphasis on the citations, promised in the Plan, is delivered in the "Preface" and strengthened. "The solution of all difficulties, and the supply of all defects, must be sought in the examples" (444). Whatever accent there had been on correcting faults has been leavened with doubts, lightened - one senses — with a shift of responsibility from Johnson to his sources. "Most men think indistinctly, and therefore cannot speak with exactness... This uncertainty is not to be imputed to me, who do not form, but register the language" (452).

Fixing pronunciation is now reduced to marking as distinct from the norm the stress placed by poets whose accentuation varies from the customary. There seems no effort to distinguish the accent of one region or class. All decisions taken on other matters may be appealed: "the orthography which I recommend is still controvertible; the etymology which I adopt is uncertain, and perhaps frequently erroneous" (452). Any hope to provide every word "a definition strictly logical" is dashed, or proved "the dreams of a poet doomed to wake a lexicographer" (452). The dictionary can neither embalm, nor perfect, nor exactly describe the language.

In the Plan Johnson had taken the academies to task, not for promising a refuge from mutability for their tongues, but for thinking any language (or dictionary) capable of perfection (442). In the "Preface" he describes their activities with images of policing; academies are to "guard avenues, to retain fugitives, and repulse intruders" (453). Their sort of law is impossible to enforce, for "sounds are too volatile and subtile for legal restraints" (453).

While conceding that we cannot restrain new words or meanings of particular words from coming into the language, but Johnson thinks it possible to defend - "legally" — English style. Cheek by jowl in two of the closing paragraphs of the "Preface" are a rousing attack on what an academy would mean for English and a rousing call to choose the path of an evolving English as it evolves. After distinguishing "the single stones of the building" from "the order of the columns", Johnson makes it clear that he is a prescriptivist with respect to the latter: "Tongues, like governments, have a natural tendency to degeneration; we have long preserved our constitution, let us make some struggles for our language" (454).

The key to this key passage is the introduction of "English liberty" to the running comparison between how languages and realms are governed. Full treatment of this point will require a discussion in detail of Johnson's consistent use of legal terms, legal images, and legal logic in the Plan and the "Preface"; of the "history of English liberty" as imagined by common-law writers of the seventeenth and eighteenth centuries will provide the centre for much of the discussion. For the moment, it suffices to note that the concept opposed to "academies" is precisely "English liberty":

No book was ever turned from one language into another, without imparting something of its native idiom; this is the most mischievous and comprehensive innovation; single words may enter by thousands, and the fabric of the tongue continue the same; but new phraseology changes much at once; it alters not the single stones of the building, but the order of the columns. If an academy should be established for the cultivation of our style; which I, who can never wish to see dependence multiplied, hope the spirit of English liberty will hinder or destroy... (454)

Johnson invokes English liberty and the English constitution; he takes a pretty dramatic stand on behalf of the "order of the columns" without stating outright what order, which columns. The English constitution is a set of traditions as to who is who and how they should get along; the English constitution is what gets done, just as style is what gets written and then read (and later taught). Johnson is as much a supporter of notions of correctness as he is of the basic political conventions of his day, but the correctness he supports is, at its base, a set of relations between private individuals and the decisions that govern those relations, decisions taken by judges acknowledged by the same private individuals. The law of the English constitution is the result of court decisions as to the rights of private individuals (Paton 277). The chief distinction between language and law is that the private individual may ignore the judgments handed down with respect to language and risk only a corrector's pen. 
In summary: what the Plan promises is more ambitious than what the "Preface" says the Dictionary delivers. In the Plan there is more talk of fixing the language, in the "Preface" of displaying it. Neither stage of the project shows hopes for achieving a Continental standard, though there is more admiration for the academies' work in the Plan, less in the "Preface". The "Preface" is hostile to the idea of an English academy, and it accords an even greater power to common usage than is granted in the Plan - the power, for example, to make a word obsolete (454). Neither text expounds linguistic principles from which a standard is forever to be derived deductively. Both adduce their standard from custom, past usage, reason and analogy. In neither essay does Johnson think language can be made immune to change; in the "Preface" he makes a longer, more detailed and more moving admission to this effect. In his most conservative moment Johnson calls upon speakers of English to resist the "changes that we fear be thus irresistible," as he considers it imperative that "we retard what we cannot repel, that we palliate what we cannot cure" (454). He means changes introduced by "illiterate writers" or via "frequency of translation" (454) - only two sources of change among perhaps nine so discussed. ${ }^{1}$ That much change is to be neither welcomed nor feared, but observed as a part of custom, is more likely to seem Johnson's last word on fixing the language:

Swift, in his petty treatise on the English language, allows that new words must sometimes be introduced, but proposes that none should be suffered to become obsolete. But what makes a word obsolete, more than a general agreement to forbear it? (454)

To review: Johnson's philological techniques are a mixed bag including description of general usage, induction from a sometimes confusing, sometimes conflicting line of precedents, as well as analogy, grammar, and reason. Where past usage is not consistent, Johnson will let both sides have it out in a controversia and endeavour to discover and promulgate the decrees of custom. Final judgment is effectively suspended. The emphasis is on the probable rather than the certain.

The authority setting up a standard English, in the Plan, is vetted and assented to by Chesterfield; in the "Preface", the emphasis is on liberty rather than on authority, there being a throwing back of authority onto the examples given in the Dictionary entries, and forward - by way of the emphasis on liberty - onto the reader. Authority resides in a body of principles slowly evolved by the decision of concrete cases.

Johnson makes the study and the governing of language, in the Dictionary and elsewhere, two stages along one path. How to study and how to "govern" English common law are equally but two aspects of the intellectual and political crisis of the seventeenth century. Seventeenth-century law leads to eighteenth-century lexicography by two routes: the former begins in the late Tudor period, when lawyers begin to call for a restatement of the law. It leads through Bacon to his great rival Coke, and thence to the Civil War. The latter begins with the multiplication of jurisdictions under the Tudors; its course will take us to a controversy over the sources of law, the power to delimit jurisdiction, and ultimately to questions of sovereignty. Beyond the Civil War and the Act of Settlement there lies a national myth, a system of beliefs about the conflict between Parliament and the Stuart kings, and therefore about Coke, the common lawyers, and their ancient constitution. Johnson, in his rousing defence of the English language and English basic law, either unwittingly renewed a one-hundred-and-fifty year-old connection or showed that in these matters, as in so many, his learning was astonishing.

\section{THE Vocabulary of COMmon LaW}

So many ancient terms and words drawn from the French are grown to be vocabula artis, vocables of art, so apt and significant to express the true sense of

1. The other seven sources of change are conquests, migrations, study of foreign languages, commerce, increase of knowledge, levity and ignorance, and the passing away of customs. 
the laws, and are so woven in the law themselves, as it is in a manner impossible to change them, neither ought legal terms to be changed. (Coke xxxix)

The stuff of English law is not, according to Frederick Pollock and F. W. Maitland, “just a mixture or compound of two old national laws" (80), of Edward the Confessor's and William the Conqueror's. The terminology, however, is mainly of French origin. To cite a few examples: the English terms proper to public law include earl, sheriff, king, queen, lords, knights, and shire; the French, parliament, statute, privy council, ordinance, commons, realm, sovereign, state, nation, the people, and citizens. In private law deeds, wills, and bonds are English; contract, agreement, debt, bill, partner, guarantee, property, lien, marriage, guardian, infant, and ward are French. If we are arraigned, the charge may be one of trespass, assault, battery, slander, treason, arson or larceny. Felonies are distinct from misdemeanours. Proceedings involve courts, justices, judges, jurors, counsel, attorneys, clerks, parties, plaintiffs, defendants, actions, suits, claims, demands, indictments, counts, declarations, pleadings, evidence, verdicts, convictions, sentences, appeals, reprieves, and pardons, all of them French. Only witness, writs and oaths are English. Most of the vocabulary of policing and punishment is French; only outlaws and the gallows are English, and they are both things of the past. ${ }^{1}$

From the eleventh to the sixteenth century, French was chief among the languages of the law. Latin, by the time of Henry II, had become the language of the highest official record-keeping, of the king's acts and his court's judgments; and of the most formal classes of legal instruments. French came to be used for the parliament and statute rolls, and for pleading. Pollock and Maitland date the undisputed predominance of French from 1166, when a decree was issued giving "to every man dispossessed of his freehold a remedy to be sought in a royal court, a French-speaking court" (84). French remained the language the law spoke until the mid-fourteenth century, when English was decreed for pleading.

The records of the English legislature were kept entirely in French until 1425, and partly in French until 1503. Perhaps more importantly, treatises on English jurisprudence were written in French from the thirteenth century on, and the law reports on arguments and decisions known as the Year Books - the most important record of medieval case law - were in French. As late as 1612 Sir John Davies, then Attorney-General for Ireland, was defending law French, whose replacement by any other language would, he thought, result in a serious loss to the law's intelligibility (Pocock 34).

Coke's "vocables of art" were thus, both for statute and for case law, old words often to be found embedded in what was no longer the language of state. Aspirants to the bar achieved mastery of legal terminology "not by reading books but by observing actual pleadings conducted in the courtroom" (Conley 134). The teaching methods of the Inns of Court presupposed some training in rhetoric; and the twice-yearly Reading, the major task undertaken by students, was in part exegetical (Vickers 40). That some were able to take full advantage of this educational programme is evident from Coke's works and Bacon's ambitions: both men thought themselves well enough trained to restate the law.

\section{COMMON LAW UNDER THE TUDORS}

Tudor law was a complex mass of almost infinite particulars, a mix of modern and ancient legislation, of accumulated lore, decisions, and maxims: terms, precepts, precedents, and statutes from many centuries co-existed without any codification. Bacon summarised the situation thus:

1. The word lists and history have been taken from so many sources that I will limit my citatations to a short, basic bibliography: for the vocabulary of law and order, courts of law, legal work, the police, crime, prison, and punishment see Tom McArthur's Longman Lexicon of the English Language 122-41; for specific etymologies, see Oppé; for accounts of lexical change in professional registers in the Middle English period, see Strang 213-81 and Williams 65-90; for a legal historian's perspective, see Allen. 
Certain it is that our laws, as they now stand, are subject to great incertainties, and variety of opinion, delays, and evasions: whereof ensueth (1) that the multiplicity of and length of suits is great. (2) That the contentious person is armed, and the honest subject wearied and oppressed. (3) That the judge is more absolute; who, in doubtful cases, hath a greater stroke and liberty. (4) That the chancery courts ${ }^{1}$ are more filled, the remedy of law being often obscure and doubtful. (5) That the ignorant lawyer shroudeth his ignorance of law in that doubts are so frequent and many. (1874, VI, 64)

The legal historian W. S. Holdsworth records there having been a project before Parliament in 1593 "to enter into a general amendment of the state of laws, and to reduce them to more brevity and certainty" (V, 485). Bacon's own proposal for a restatement of the law was "of a sort not unlike that which Justinian applied to Roman law" (Holdsworth V, 487). It was not to have been a logical code, for "I dare not advise to cast the law into a new mould... a perilous innovation" (Bacon 1874, VI, 67). Nor would it have done away with the authority English law gives to reported cases. Rather, Bacon's proposal entailed streamlined digests of case law and statute law, omitting obsolete and overruled cases and resolving difficult points. The basis of case law - the Year Books and other judicial reports - was to have been preserved in libraries, for the digests would not have wholly superseded them. Three other works were to have been composed at the same time as the digests: a textbook on private law, another on general principles and procedure, and a book of terms. This last was planned as "a dictionary both of ancient and modern words, arranged, not according to the order of the alphabet, but on the principle of putting together words relating to the same thing" (Holdsworth $\mathrm{V}, 488$ ). ${ }^{2}$ Bacon stresses that his dictionary was to include "not only the exposition of the terms of law, but of the words of all ancient records and precedent" (1874, VI, 70).

Bacon never finished this scheme. It was left to Coke to publish the first of his Institutes in 1628 , two years after Bacon's death. Bacon had been forced from office in 1621, and Coke from the Bench five years before; both busied their retirement with writing, but Coke lived long enough to draft the Petition of Right, and to lead the parliamentary opposition to Charles I. English common law bears his stamp rather than his rival's. If Bacon had lived another ten years the course of the law would have been more analytical, less historical; yet conditions were right for either project to prosper:

[The sixteenth century] was a century in which there had been enormous changes in men's religious and political ideas, and an enormous mass of legislation directed

1. The Court of Chancery administered the rules of equity as opposed to the rules of common law; equity denotes the mitigation of the ordinary rules of law where they would operate harshly in a particular case. It is at the mercy of a Chancery decision in the case of Jarndyce v. Jarndyce that Richard Carstone and Ada Clare find themselves in Dicken's Bleak House.

2 . There had been a glossary of obsolete ecclesiastical and legal terms, Sir Henry Spelman's Archaeologus, the first volume of which was published in 1624. More significant is The Interpreter (1607), a dictionary of legal terms by John Cowell. Cowell, who had been Regius Professor of Civil Law at Cambridge from 1594, resigned his chair in 1611 after the House of Commons ordered his book burnt by the common hangman. He is supposed to have advanced the opinion that the prerogative of the English crown was absolute, and that the king only consulted parliament by suspending his absolute power to make laws, which was otherwise inviolate. According to the DNB, The Interpreter was disavowed by James I. Both Bacon and Coke are said to have played some part in Cowell's downfall, Coke's hostility being expressed in references to 'Dr Cowheel'. Cowell's original was reissued in 1637 and 1658. A copy of the edition of 1607 is to be found in the Supreme Court of Canada Library, and there have been a number of modern facsimile editions. Editions from 1684 onwards (1701, 1709, and 1727) are expurgated, and the key entries on 'king', 'parliament', 'prerogative', 'recoveries', and 'subsidies' greatly altered. One of these bowdlerised editions was used by Johnson in preparing the list of authorities for the Dictionary, and a cursory inspection of the entries for both common and civil law terms suggests that Cowell is the most frequently cited legal author. However, the 1684 edition already bears the stamp of Coke's and Hale's views on sovereignty, law, and the doctrine of precedent: the 1607 entry on 'parliament' argues that the king is above positive law, and cites Aristotle; that of 1684 describes the assembly of the king and the three estates of the realm, and cites Coke's Institutes. 
to settling the nation on the basis of these new ideas. [It] was therefore needed to bring the medieval basis on which the law rested into harmony with the new situation. (Holdsworth V, 489)

The common law, antiquated by the drag of its own intellectual baggage and pushed to compete with the prerogative courts, "suffered from the serious defect of being politically weak in an age of keen political controversy" (Holdsworth V, 422). Yet the common law had undergone "a great hardening and consolidation" of its system of thought (Pocock 31), and lawyers held more tenaciously than ever that a native, insular, immemorial system of customs ruled those who ruled England. Because of its medievalism, the common law sanctioned political theories which were subject to ever greater challenges, and which were defended ever more strenuously. That any successful early seventeenth-century restatement of the common law would enjoy vast prestige and influence is evident: a strengthened common law was precisely the ally Parliament needed.

\section{SiR EDWARD COKE's INSTITUTES}

A more extensive discussion of Coke's impact on constitutional law will be provided later in this paper. The present concern is his work on the vocabulary of English law. Holdsworth describes the first volume of the Institutes - a commentary on a treatise by the medieval jurist Littleton - as " a legal encyclopedia arranged on no plan, except that suggested by the words and sentences of Littleton" (V, 467). It is more properly an encyclopedic dictionary, for Coke introduces every full discussion of a point of law with a history and definition of the terms involved. "It is apparent," writes Holdsworth, "that he considered himself somewhat of an authority on etymology" (V, 459). Coke, whose views were those of an Elizabethan jurist and did not evolve, meant to give sixteenth-century meaning to what were often feudal terms; to that end he had to trace words through centuries of statutes, treatises, and law reports, noting the changes and developments - semantic and legal — which had occurred since Littleton wrote. The learning implied is vast: "All Coke's reading in the older text books, in the Year Books, abridgements, and records, in modern legal writers, in general literature, are pressed into this service" (Holdsworth $\mathrm{V}, 467)$. Coke goes so far as to expound on Littleton's use of “etcetera” (17a).

Coke knew that his undertaking was in part philological; for Coke wrote, in English, a commentary on a text in French. He was a conservative jurist, but not so conservative as to continue a moribund tradition of English jurisprudence written in French. Typically, he applied common-law reasoning to his choice of language:

This part we have (and not without precedent) published in English, for that they are an introduction to the knowledge of the national law of the realm; a work necessary, and yet heretofore not undertaken by any. We have left our author to speak his own language, and have translated him into English, to the end that any of the nobility or gentry of this realm, or of any other estate or profession whatsoever, that will be pleased to read him and these Institutes, may understand the language wherein they are written.

I cannot conjecture that the general communicating of these laws in the English tongue can work any inconvenience, but introduce great profit, seeing that Ignorantia juris no excusat, Ignorance of the law excuseth not. And herein I am justified by the wisdom of a parliament; the words whereof be... (xxxviii-xxxix)

"Our author" is Littleton, and to write on him in English is justified by the precedent of other jurists, by two Roman maxims (another is coming, after a long quotation of an Elizabethan statute), and by reference to legislation.

Coke's technique is to present Littleton's text section by section, followed by commentaries on specific phrases. "The commentary itself is of extraordinary verbal minuteness... and of an equally remarkable fullness," writes Holdsworth. "Every word, every doctrine, every legal institution, is explained" (V, 467). A large number of miscellaneous legal topics are grouped around the ostensible matter at hand: Littleton's treatment of the land law. An historically 
important definition of common law thus appears appended to a discussion of the qualifying phrase "Insomuch that such title of prescription was at the common law" at the end of a section on tenure in burgage (115a). The somewhat jumbled effect is nonetheless taken by legal historians to be the dividing line between medieval and modern law, and the unquestioned foundation of the latter. ${ }^{1}$

The Institutes' philological commentaries comprise etymologies, citations, and a reasoned discussion of meaning. Though Coke does not take meaning to derive strictly from word origins, he is nonetheless careful to begin his "entries" with etymology. Dower is traced through French to the Latin "ex donatione, et est quasi donarium" (31a); derivations are given both for the English "timber" and the French equivalent marreim or marrein, for "it is good to fetch them both from the original" (53a). Where rival derivations exist, they are described:

'A le seneschal,' (which we call a steward). Seneschallus is derived of sein, a place, and schale, an officer or governor. Some say that sen is an ancient word for justice, so as seneschall should signifie officiarius justitice; and some say that steward is derived of stewe (that is) a place, and ward, that signifieth a keeper, warden or governor. (61b)

Bailife Coke treats similarly, defending a Saxon derivation against a Latin one (62a); in giving the etymology of "reeve" he describes processes of "contraction or rather corruption" by which the Anglo-Saxon original was altered (62b).

If etymologies are important, examples are authoritative. "Coke drew his precedents from very old sources," writes Holdsworth,

- the older the source, he thought, the purer the law. He naturally represented the law of his own day as the logical outcome of the law laid down in his older sources. The newer decisions had not changed the law - they had merely developed or explained the truth to be found concealed in the older authorities. (V, 473)

Thus meaning is historically conditioned, and it is best understood as one moment in a process. To document such a process Coke sometimes inserts quotations from earlier jurists; though he more often provides a list of references to sources of all categories. Such references include abundant citations of case law.

Further illustration of these techniques would only serve to display the consistency with which they are applied. Two more observations might profitably be made: first, Coke often gives a contextual definition of a legal term after a more general discussion of its origin and meaning. The above-mentioned passage on "seneschal" continues thus:

But it is a word of many significations. In this place it signifieth an officer of justice, viz. a keeper of the courts, \&c. Fleta describeth the office and duty of this officer at large most excellently. $(61 b)^{3}$

Second, Coke often begins his treatment of issues, whether semantic or legal, with a partitio, a division of the whole into parts. Partitio announces to the reader that a topic will be dealt with through a clearly defined scheme of headings and sub-headings. It comes into English law and Re-

1. "His writings form the starting-point of the modern as distinct from the medieval common law, because in them medieval rules are so harmonized with the modern additions, that they fitted the common law to guide the future legal developments, not only of England, but also of the many dominions which Englishmen were to found beyond the seas" (Holdsworth V, 424). Similar views of Charles Butler's, Sir James Stephen's and F.W. Maitland's are quoted in Holdsworth.

2 . It is interesting to note that the first quotation given for the legal sense of dower in the $O E D$ is from the thirteenth-century jurist Britton and is written in French.

3 . The name of the author of the tract Fleta, seu Commentarius Juris Anglicani (circa 1285) is not known. Traditional legal scholarship has classified this treatise as an imitative commentary on and appendix to the work of Bracton. 
naissance rhetoric in general from Cicero and Quintilian, and was a tactic law students were expected to employ in their Readings (Vickers 36-40). In Coke the partitio often means more careful definitions, and finer distinctions between senses of quite common words:

There be two kinds of waste, viz. voluntary and actuall, and permissive. Waste may be done in houses, by pulling or prostrating them down, or by suffering the same to be uncovered, whereby the spars or rafter, plaunchers, or other timber of the house are rotten. (53a)

\section{SIR EDWARD COKE's INSTITUTES: CONCLUSION}

I hope that my juxtaposition of Johnson's lexicographical and Coke's jurisprudential principles will have made a few parallels clear. To begin with, both value tradition even above reason, and both are extremely conservative. Holdsworth agrees with Coke's critics that much obsolete law was preserved because of the Institutes (488); and Blackstone, who nevertheless affirms that Coke's works are of intrinsic authority in a court of law, calls Coke's scholarship "not a little infected with the pedantry and quaintness of the times he lived in" (72). Johnson, of courses, rages against systematic change at every opportunity. And he equally opposed a sovereign executive power's ability to regulate systems of human knowledge: what Coke denied of the courts of royal prerogative, Johnson denied of the academies.

The desire to trace a word's meaning and usage from a root in another language, through centuries of evolution to a number of contemporary senses, is common to both authors. Johnson's reverence for common usage and dependence on precedent echo Coke's definition of the common law:

"Common law." The law of England is divided, as hath been said before, into three parts; 1 , the common law, which is the most generall and ancient law of the realm; 2, statutes and acts of parliament; and 3, particular customs. I say particular, for if it be part of the generall custome of the realm, it is part of the common law. ${ }^{1}$

The common law has no controler in any part of it, but the high court of parliament; and if it be not abrograted or altered by parliament, it remains still, as Littleton here saith. The common law appeareth in the statute of Magna Carta and other ancient statutes (which for the most part are affirmative of the common law) in the original writs, in judiciall records, and in our bookes of termes and yeares. $(115 b)$

One might even argue for a parallel between particular custom - custom established in one place or among one group - and Johnson's notion of peculiar senses found in the greatest writers. Both are there because they cannot easily be got around.

Another parallel has to do with the role of the judge or lexicographer. Although the system of precedents, the worship of induction, and the lack of a code in the Continental sense have led some to call common law "judge-made", judges merely declare custom to be operative law. Later judges may differ in their judgments from such precedents as are not binding; it is declared that the earlier sentence was not law rather than bad law (Blackstone 70). Custom does not derive its inherent validity from the authority of the court. Johnson in the "Preface" likewise asserts that his chief function is to "register the language" (452) rather than to form it. Before the examples in which the "solution of all difficulties, and the supply of all defects, must be sought" (451), Johnson - without forfeiting his own right to pass judgment - recommends that the reader be the judge, and leaves older authors' spelling unaltered (447).

1. The same three-part treatment of English law is to be found in the eighteenth-century jurist William Blackstone (63-64) and in contemporary textbooks (Paton 51). 
Law and language structured after experience and custom contrast with Continental attempts to find stabler authorities from which decisions about words and justice might be deduced. Just as the French and Italian academies sought means of making their vernaculars more fixed and thus more classical, there arose in the Renaissance a movement among European jurists to revive - or "receive" - classical Roman law in place of the feudal, customary law of the Middle Ages. The latter had not gone entirely un-Romanised, but the Reception consisted in an effort to return to the strict letter of classical texts, especially of the codification of Roman law ordered by Justinian. It is important to note that the Reception had some influence in England: Henry VIII founded Regius Professorships in civil law at Oxford and Cambridge, and the "civilians" formed the main corps of judges in the prerogative courts (Plucknett 44). On the Continent the Reception meant a desire to construct a legal system analogous to Euclidean geometry, with deductions being made by rigorous logic from unshakeable axioms (Paton 151); this desire produced the codes on the basis of which the legal system functions in France (1804), Germany (1900), and the majority of modern European states. Although a long course of decisions may have highly persuasive authority in Continental countries, in practice they are seldom sought out or referred to.

Johnson's trust that English liberty would destroy an academy, and his call to the English to defend their language as they had their constitution, are here in their proper context. That eighteenth-century Englishmen associated the Reception with a loss of traditional rights is apparent in this comment, almost coeval with the Dictionary, of William Blackstone's:

These are the laws that so vigorously withstood the repeated attacks of the civil law, which established... a new Roman empire over most of the states of the continent: states that have lost, and perhaps on that account, their political liberties; while the free constitution of England, perhaps upon the same account, has been rather improved than debased. (67)

English law, as an organic body of principles with an inherent power of growth and adaption to new circumstances, is profoundly historicist. ${ }^{2}$ "Law," writes Paton, "lays down what is convenient for that time and place" (68), and the basis for such laying down is present fact and past wisdom. Law may be unjust without ceasing to be law, just as language may impede rather than facilitate communication and still be language. Johnson's paragraph ${ }^{3}$ against Adamic language in the "Preface" and a passage of Paton's 4 on the doctrine of the logical plenitude of the of the law use the same image to make much the same point, despite the difference in tone: experience is, as Coke said of the law, a kind of artificial reason, an emancipation from the intellectual atmosphere of any one age.

1. I once had occasion to visit the law library of Bufete Cuatrecasas, a Barcelona-based law firm that is the largest in Spain. It seemed astonishingly small: the endless rows of law reports that English-speakers associate with such a setting were nowhere to be seen.

2 . Indeed, it was Coke's favourite proverb that "[o]ut of the old fields must grow the new corn" (Holdsworth 479).

3 . "Speech was not formed by an analogy sent from heaven. It did not descend to us in a state of perfection, but was produced by necessity, and enlarged by accident, and is therefore composed of dissimilar parts, thrown together by negligence, by affectation, by learning or by ignorance" (442).

4. "This theory is not only logically justifiable but historically true, for we cannot imagine the whole body of common law descending from heaven and containing, even implicitly, the developed modern distinctions" (151). 


\section{CONSTITUTIONAL CONSIDERATIONS}

Coke's reputation among later common lawyers is hard to overestimate. ${ }^{1}$ It is true that he was attacked by Thomas Hobbes - not a lawyer - and that the analytical school of Jeremy Bentham and John Austin took a dim view of his entirely historicist jurisprudence. Yet even Austin acknowledged that "Coke's mastery of the English legal system as a whole was equalled only by the great Roman jurists" (qtd. in Holdsworth V, 482). He is the sort of thinker referred to nowadays as "the founder of a discourse".

That he should have attained such a status has as much to do with the critical moment in which his works were published as with their inherent merits. The second (on public law), third (on criminal law), and fourth (on jurisdiction) volumes of the Institutes were published posthumously, thirteen years after the above-described commentary on Littleton. In that year, 1641, the Long Parliament abolished the prerogative courts; a gap was created, as matters attended to by the Star Chamber, the court of Admiralty, and the court of Wards were thrown back to the common law courts. Coke's restatement of English common law filled that gap, and his writings were made the basis of modern English constitutional law. As stated above, the courts of royal prerogative were not re-established in 1660, and Pocock thus calls the Restoration, "the greatest triumph which the cult of the ancient constitution ever enjoyed" (156). Nor were Coke's constitutional doctrines to be questioned at all after 1689. Pocock, in The Ancient Constitution and the Feudal Law, shows that Coke's historiography was not seriously challenged until the 1680s, when the challenger - Dr Robert Brady, keeper of the Tower records under James II - lost his position as a result of the Glorious Revolution. His successor, William Petyt, used arguments out of Coke and the midcentury Chief Justice Sir Matthew Hale to justify to the House of Lords the assertion that there had never been a contract between the king and the people for James II to break, because "the contract might be a most liberal and rational concept, but they [Petyt and his fellow commissioners] could not find it in the laws of England" (Pocock 230). ${ }^{2}$ One of the Whig apologists, William Atwood, presented Locke's Two Treatises as laudable philosophy which the revolution's defenders need not use, because they could argue - as men had argued since 1628 — from history (Pocock 360).

By means of an appeal to immemorial custom, the English, uniquely, had, avoided the need to posit a single ancient individual by whose sovereign will the law was first made, and by whose remotest descendant — the reigning monarch — that law could be taken away. So the "balanced English constitution" meant, in the eighteenth century, a weakened executive, parliamentary power, and a degree of personal freedom that allowed discussion of political and other topics. By Johnson's time,

England ... had secured a native body of law continuously developed on its own lines, and the supremacy of the law over all persons, and even over the prerogative of the King. (Holdsworth, X, 5)

Johnson's analogy of the English language and the English constitution is tricky: language may be something we do, something we are, something we use or something in the midst of which we live, but it is not a fixed body of laws and principles according to which anything is governed. Even if language controls us, it cannot be drafted and submitted to referendum, nor amended; it has no articles whose letter and spirit may be variously interpreted by political leaders and judges. Language is neither as neatly organised nor as wilfully planned as is fundamental law.

It is as though Johnson were pleading parallel cases on behalf of a system of words and another of government. There is, in the Dictionary, some idea of propriety, of an order that is at least suitable if not right in the sense of just and morally good. There is a sense that language is an

1. For a discussion of Coke's impact on non-legal thinkers by a non-legal historian, see the whole of Chaper $\mathrm{V}$ in Christopher Hill's Intellectual Origins of the English Revolution.

2 . Hale's rebuttal to Hobbes's Dialogue of Common Laws had emphasised the common law as an evolving response to history whereas Coke had stressed its unchanged character; but both considered it immemorial and rooted in the precept that accumulated wisdom "should not be too readily subjected to the criticism and amendment of individual reason" (Pocock 171). 
instrument, that such an instrument may be shaped to our purposes, that it may be judged more or less useful, more or less efficient. Despite the gifted apologist it found in Orwell, clarity has lost ground in our century: ambiguity, as a stylistic trait, commands greater interest. Anyone interested in clarity, in language that expresses rather than prevents or obscures thought (Orwell 365), will see that it has to be learned and worked at, that it comes of training. Language is more a thing governed than a scheme for governing, but if we speak instead of skill at language the two are intertwined.

Johnson calls for a defence of "our language" to parallel the long struggle for "our constitution" - and perhaps the twice-repeated word is the most important of the three. For the prescriptivist lexicographer, the linguistic equivalents of the country and its constitution both go into the dictionary; for the patriotic lexicographer there may exist "our" way of knowing and ordering things, applicable in equal measure to realms and words. Johnson's concern is with national identity as rooted in tradition-bound or at least tradition-derived practices and knowledge whose validity depends, at least in part, on their fitting vaguely together.

"We have long preserved our constitution": the emphasis is on continuity, on there not being a before and an after. English constitutional law was and is a part of the common law, and Johnson's analogy depends for its effect on our understanding what common law was preserved, and how. Paton's account of the meaning the phrase "rule of law" has enjoyed since 1689 is as follows: regular law is supreme over arbitrary power; officials must obey the law, and are subject to the jurisdiction of ordinary courts; and constitutional law is based on judicial decisions as to individual rights (277). Coke addresses each of these points in his writings. Thus, on the first count: in a debate Coke had with James I in November, 1608, the King said he was the supreme judge,

inferior judges his shadows and ministers... and the King may, if he please, sit and judge in Westminster Hall in any Court there, and call their Judgments in question. The King being the author of the Lawe is the interpreter of the Law. (qtd. in Holdsworth V, 428n)

Coke's reply, as recorded in one of his own Reports, ${ }^{1}$ was that the king could neither judge cases nor remove cases nor decide on disputed jurisdiction. James insisted that the application of such a doctrine meant that he would be under the law, which was treason to affirm. "Bracton" saith," replied Coke, "quod Rex non debet esse sub homine, sed sub Deo et lege" (430). Cause for dismissal indeed.

On the second count, Coke maintained in the Parliament of 1628 that imprisonment by the king's special command, or by the Council's, was illegal (450). On the third, it is enough to recall that Coke presented to Parliament "An Act for the better securing of every freeman touching the propriety of his goods and the liberty of his person" (451). Its provisions became the Petition of Right.

Coke's restatement was not a tidying up; he argued on the basis of medieval rules of law that are sometimes obscure and indefinite. That something that can only be groped at, that cannot be fixed, nor made into a code, should be the fount of English law has supposed a degree of flexibility

1 ." It seems likely that Coke, having attended several Council meetings at which the king expressed his views as to the subordination of the law to the king, gave a narrative in which he states the royal views, added authorities in favour of his own views, and threw it into a literary form which bears little resemblance to the spoken words used of this particular occasion." (Holdsworth V, 430n).

2. The medieval treatise entitled De legibus et Consuetudinibus Angliae is attributed to Bracton, but little is known of the author. Composed in the latter half of the thirteenth century, Bracton's work represents a thorough survey of the rules of property and the proceedings in actions, supported by deduction or corroborated by the authority of adjudged cases. Bracton was looked up to as the foremost source of legal knowledge until the Renaissance. 
and a capacity for development and expansion. That Johnson, who knew some law, ${ }^{1}$ should havge favoured a similarly custom- and precedent-bound, highly conservative scheme is not in the end surprising. The Dictionary proposes a balanced linguistic constitution, free from arbitrary powers, open to the operation of reason upon experience, admitting - however grudgingly — change. It is a monument to what was thought to be the character of a nation (of course, we must not reify such things nowadays: but Johnson did), a spirit Bacon described in these words:

The people of this kingdom love the laws thereof, and nothing will oblige them more than an assurance of enjoying them: what the Nobles once said upon occasion in Parliament Nolumus leges Angliae muture, is imprinted in the hearts of all the people. (1874, VI, 33)

\section{WORKS CITED}

Allen, Sir C. K. 1964: Law in the Making. 7th ed. Oxford, Clarendon.

Bacon, Francis 1974: The Advancement of Learning and New Atlantis. Ed. Arthur Johnson. Oxford, Clarendon.

Bacon, Francis 1874: The Letters and the Life of Francis Bacon. Ed. James Spedding. 7 vols. London, Longmans.

Blackstone, William 1979: Of the Rights of Persons. Introd. Stanley N. Katz. Chicago: U of Chicago P. Vol. 1 of Commentaries on the Laws of England: A Facsimile of the First Edition of 1765-1769. 5 vols.

Boswell, James 1979: The Life of Samuel Johnson. Ed. and abr. Christopher Hibbert. Harmondsworth, Penguin.

Coke, Edward 1832: The First Part of the Institutes of the Laws of England; or, a Commentary Upon Littleton. Ed. Charles Butler. 19th ed. London, Clarke.

Conley, Thomas M. 1990: Rhetoric in the European Tradition. Chicago, University of Chicago Press.

Hill, Christopher 1965: Intellectual Origins of the English Revolution. Oxford, OUP.

Holdsworth, W. S. 1951: A History of English Law. 3rd ed. 12 vols. London, Methuen.

Johnson, Samuel 1835: The Works of Samuel Johnson. Vol. 2. New York: Dearboon. 2 vols.

McArthur, Tom 1981: Longman Lexicon of the English Language. London, Longman.

Oppé, A. S. 1938: Wharton's Law Lexicon Forming an Epitome of the Laws of England Under Statute and Case Law. 14th ed. London, Stevens and Sons.

Orwell, George 1984: The Penguin Essays. Harmondsworth, Penguin.

Paton, G. W. 1951: A Text-Book of Jurisprudence. 2nd ed. Oxford, Clarendon.

Plucknett, Theodore F. T. 1956: A Concise History of the Common Law. London, Butterworth.

Pocock, J. G. A. 1987: The Ancient Constitution and The Feudal Law: A Study of English

\footnotetext{
1. Johnson knew enough law to discuss in great detail the activities that British judges in India might engage in (Boswell 172); he affirmed that he "ought to have been a lawyer", and that Johnson's Reports would have meant as much to the world as the Dictionary (253); and he became agitated when a lawyer suggested that, had Johnson taken to the law, he might have been Lord Chancellor of Great Britain. Johnson exclaimed in an angry tone, "Why will you vex me by suggesting this, when it is too late" (254).
} 
Historical Thought in the Seventeenth Century. Rev. ed. Cambridge, CUP.

Pollock, Sir Frederick, and F. W. Maitland 1982: The History of English Law. New York, Legal Classics Library.

Sledd, James H., and Gwin J. Kolb 1955: Dr Johnson's Dictionary: Essays in the Biography of a Book. Chicago, University of Chicago Press.

Strang, Barbara M. H. 1970. A History of English. London, Methuen.

Williams, Joseph F. 1975: Origins of the English Language. New York, Free Press.

Vickers, Brian 1968: Francis Bacon and Renaissance Prose. Cambridge, CUP. 